\title{
NILAI-NILAI KERUKUNAN DALAM KEARIFAN LOKAL MASYARAKAT BAWEAN GRESIK
}

\author{
The Harmony Values in Local Wisdoms of \\ Bawean Gresik People
}

\author{
Rosidin \\ Balai Penelitian dan Pengembangan Agama \\ J1. Untung Suropati Kav. 70 Bambankerep Ngaliyan Semarang 50185 \\ Email: nazalnifa@yahoo.co.id
}

Naskah diterima tanggal 6 Februari 2015. Naskah direvisi tanggal 9 Maret 2015. Naskah disetujui tanggal 22 Mei 2015

\begin{abstract}
Abstrak
Setiap suku bangsa di Indonesia hampir memiliki acuan norma-norma yang bersumber dari kebudayaan masing-masing, yang dikenal dengan kebijakan budaya lokal (local genius) atau kearifan lokal (local wisdom), termasuk masyarakat Bawean Gresik. Penelitian ini untuk mengetahui kearifan lokal sekaligus bagaimana nilai-nilai kerukunan umat pada kearifan lokal masyarakat Bawean. Pendekatan penelitian kualitatif-deskriptif, artinya peneliti mencari deskripsi yang menyeluruh, mendalam, dan cermat tentang kearifan lokal di masyarakat Bawean. Selanjutnya, digambarkan bagaimana kearifan lokal berperan dalam memelihara kerukunan umat secara terbuka alamiah. Adapun hasil penelitian ini (1) masyarakat Bawean mempunyai banyak kearifan lokal hampir di setiap desa. Beberapa diantaranya: Pengantin amaen, pencak Bawean, perayaan maulud nabi, budaya merantau, dan berbagai jenis kesenian Islam; dan (2) kearifan lokal dalam berbagai bentuk tersebut mempunyai nilai kerukunan dalam hal sikap toleransi dan saling menghormati, bernilai kerja sama, dan solidaritas.
\end{abstract}

Kata kunci: kearifan lokal, kerukunan, masyarakat Bawean

\begin{abstract}
Almost each tribe in Indonesia has the reference norms derived from each of its culture, which is known with the local cultural policy (local genius) or local wisdom, included the Bawean Gresik community. The research aims to describe the local wisdom and how the harmony values among the local wisdom of Bawean society are. The research is qualitative descriptive approach; it means the researcher investigated a comprehensive, deep, and meticulous description about the local wisdom in Bawean society. Furthermore, it was described how the local wisdom played a role in maintaining the natural harmony openly. The result of this research as follows: (1) The Bawean society has a lot of local wisdoms in almost every village such as The amaen marriage, traditional self defense of Bawean, Prophet Muhammad birthday commemoration, culture abroad, and many types of Islamic arts; and (2) The local wisdoms in a variety of forms have a harmony values in terms of tolerance and mutual respect among others, cooperation values, and solidarity.
\end{abstract}

Keywords: local wisdom, harmony, Bawean society

\section{PENDAHULUAN}

$\mathrm{P}$ luralitas agama yang dipeluk oleh penduduk Indonesia telah mengilhami para pendiri bangsa bahwa negara harus menjamin kemerdekaan setiap individu untuk memilih agama yang dipercayai dan beribadah menurut agama dan kepercayaannya itu (Pasal 29 UUD 1945). Sementara itu Pasal 28I (3) UUD 1945 menyebutkan: "Identitas budaya dan hak masyarakat tradisional dihormati selaras dengan perkembangan zaman peradaban". Namun demikian, dalam menjalankan 
kebebasan itu ada pembatasan-pembatasan, artinya tidak sekehendak hati setiap orang menjalankan kebebasan beragama, tetapi harus memperhatikan hak dan kebebasan orang lain, memenuhi tuntutan yang adil sesuai dengan pertimbangan moral, nilainilai keagamaan, dan ketertiban umum dalam satu masyarakat yang demokratis (Pasal 28 ayat (2) UUD 1945).

Kenyataan yang ada, hingga saat ini kehidupan beragama masyarakat antar dan intern pemeluk agama di berbagai daerah di Indonesia masih sering terjadi konflik, baik konflik yang masih laten maupun yang sudah manifes, bahkan dengan kekerasan (violence). Kerukunan antar umat beragama di Indonesia menyisakan banyak permasalahan. Seperti kasus Cikesik, Sampang, Ambon, Lombok NTB, Kupang, Poso, dan di wilayah lainnya. Ibarat api dalam sekam yang sewaktu-waktu siap membara dan memanaskan suasana bahkan membakar sekelilingnya. Dalam konisi kehidupan beragama, maka tinggi rendahnya integrasi sosial dalam suatu kelompok keagamaan akan berpengaruh terhadap relasi sosial dengan kelompok lainnya.

Kajian atas beberapa konflik yang bernuansa agama di Indonesia, misalnya konflik umat Islam dan umat Kristen di Poso dan Maluku, agama bukanlah faktor utama (core of conflict) dalam konflik kekerasan itu, tetapi hanya menjadi faktor konsideran maupun pendukung (supporting conflict). Negara disinyalir melakukan kebijakan yang tidak afirmatif, dalam berbagai hal, proses diskriminasi dan pengistimewaan terhadap kelompok tertentu berpotensi menimbulkan konflik laten. Menurut Adan Saidi dalam Jati (2013, 395), perbincangan masalah konflik di ranah lokal bermuara pada proses marjinalisasi, ketertindasan, dan ketidakadilan sehingga isu agama kemudian menjadi stimulus dalam melakukan konflik. Penerapan standar ganda (double standart) dalam menyelesaikan konflik, yakni strategi pluralishumanis di satu sisi, dan di sisi lain menerapkan strategi penyelesaian birokratis-strukturalis, dianggap tidak mampu menyelesaikan konflik anarkis yang bernuansa agama sampai pada akar masalahnya, yaitu marjinalisasi dan diskriminasi.

Setiap suku bangsa di Indonesia hampir memiliki acuan norma-norma yang bersumber dari kebudayaan masing-masing, yaitu kebijakan budaya lokal (local genius/indeginous knowledge) atau sering disebut kearifan lokal (local wisdom). Sebagai contoh, suku Jawa memiliki pepatah "mangan ora mangan waton kumpul", suku Bali memiliki konsep "menyama braya"; suku Sasak memiliki konsep "Patut Patuh Patju”; Suku Dayak memiliki konsep "rumah betang"; suku Timor memiliki tradisi "okomama", dan sebagainya. Kearifan lokal tersebut secara spesifik berkaitan dengan budaya tertentu sehingga mencerminkan cara hidup suatu masyarakat itu. Jika kearifan lokal mampu menyelesaikan konflik kekerasan di Maluku dan Poso, seharusnya semakin dikembangkan kearifan lokal pada masing-masing daerah untuk menjaga kerukunan umat beragama. Bagi daerahdaerah yang belum menemukan konsep kearifan lokal terkait dengan kerukunan antar kelompokgolongan, maka bisa dilakukan inventarisasi atau menggali dari budaya masyarakat itu sendiri. Sangat menarik lagi apabila setiap daerah memiliki kearifan lokal (local genius) yang bisa mencegah atau tindakan preventif terhadap munculnya konflik antar kelompok agama, sehingga tidak ada lagi kekerasan yang membawa isu agama maupun isu-isu lain.

Pada masing-masing komunitas budaya itu sangat penting untuk saling mengembangkan kearifan lokalnya sebagai modal sosial (social capital) untuk menumbuhkan rasa persaudaraan yang kuat antar kelompok umat beragama. Berkaitan dengan hal tersebut, Muhammad Maftuh Basyuni, mantan Menteri Agama dalam Seminar Nasional "Kerukunan Umat Beragama Sebagai Pilar Kerukunan Nasional" di Jakarta pada hari Rabu, 31 Desember 2009 menyatakan bahwa "Pemeliharaan kerukunan umat beragama bukan hanya tanggung jawab para pejabat pemerintah di bidang agama dan pemuka agama, melainkan tanggung jawab seluruh lapisan masyarakat. Sesungguhnya masyarakat Indonesia di seluruh pelosok tanah air telah memiliki sejumlah kearifan lokal yang telah mampu menjadi penopang kerukunan umat beragama di daerah masing-masing" (Wisnumurti, 2014).

Pertanyaan yang muncul kemudian adalah bagaimana potensi kearifan lokal bisa digunakan oleh masyarakat untuk membangun dan meningkatkan kerukunan umat beragama yang berasal dari social capital yang dimilikinya. Masyarakat pemilik yang menjadi obyek kajian dalam penelitian adalah masyarakat Pulau Bawean di kabupaten Gresik Jawa Timur. Penelitian ini memiliki rumusan masalah bagaimana nilai kerukunan umat pada kearifan lokal masyarakat Bawean Kab. Gresik ?. 


\section{Tinjauan Pustaka \\ Kearifan Lokal}

Kearifan lokal merupakan sintesis budaya yang diciptakan oleh aktor-aktor melalui proses yang berulang-ulang melalui internalisasi dan interpretasi agama-agama dan budaya yang disosialisasikan dalam bentuk norma-norma dan dijadikan pedoman dalam kehidupan sehari-hari bagi masyarakat. Kearifan lokal adalah bersumber dari ajaran agama dan tradisi-tradisi yang dipelihara dan diyakini kebenarannya dan menjadi acuan dalam bertingkahlaku sehari-hari masyarakat setempat yang sifatnya mengikat anggota masyarakat tersebut. Kearifan lokal menjadi acuan masyarakat yang meliputi seluruh aspek kehidupan, antara lain: (1) berkenaan dengan aturan yang menyangkut hubungan antar sesama manusia, misalnya dalam interaksi sosial, baik antar individu maupun kelompok, yang berkaitan dengan hierarkhi dalam pemerintahan dan tata aturan perkawinan antar klan, dan tata krama dalam kehidupan sehari-hari; (2) tata aturan yang menyangkut hubungan manusia dengan alam, dan mengarah pada konservasi; (3) tata aturan yang menyangkut tata hubungan antara manusia dengan yang ghoib, seperti Tuhan, roh, dan lainnya. Dalam penelitian ini, kearifan lokal lebih ditekankan pada aspek yang berkaitan dengan interaksi sosial antar individu maupun kelompok dalam kehidupan sosial keagamaan. Kearifan lokal dapat berupa kata-kata bijak, pepatah, adat istiadat, folk lore, atau dalam bentuk setengah institusi.

Menurut John Haba (dalam Abdullah, 2008: 334-335), kearifan lokal mengacu pada berbagai kekayaan budaya yang bertumbuh kembang dalam sebuah masyarakat dikenal, dipercayai dan diakui sebagai elemen-elemen penting yang mampu mempertebal kohesi sosial di antara warga masyarakat. Terdapat lima peran vital kearifan lokal sebagai media resolusi konflik keagamaan: (1) kearifan lokal sebagai penanda identitas (signified identity) sebuah komunitas; (2) kearifan lokal sebagai ruang maupun arena dialogis untuk melunturkan segala jenis esklusivitas politik identitas yang melekat di antara berbagai kelompok; (3) kearifan lokal sebagai bagian dari resolusi konflik alternatf justu lebih ke arah mengajak semua pihak untuk berunding dengan memanfaatkan kedekatan emosi maupun kultural; (4) kearifan lokal berfungsi mendorong terbangunnya kebersamaan, apresiasi, sekaligus sebagai sebuah mekanisme bersama menepis berbagai kemungkinan yang dapat meredusir, bahkan merusak solidaritas komunal, yang dipercaya berasal dan tumbuh di atas kesadaran bersama, dari sebuah komunitas yang terintegrasi; (5) kearifan lokal akan mengubah pola pikir (way of thinking) dan hubungan timbal balik individu dan kelompok, dengan meletakkan di atas kebudayaan yang dimiliki; dan (6) kearifan lokal dapat mendorong proses apresiasi, partisipasi sekaligus meminimalisir anasir yang merusak solidaritas dan integrasi komunitas.

\section{Kerukunan Umat Beragama}

Kerukunan umat beragama adalah terciptanya suatu hubungan yang harmonis dan dinamis serta rukun dan damai di antara sesama umat beragama di Indonesia, yakni hubungan harmonis antar umat beragama, antara umat yang berlainan agama dan antara umat beragama dengan pemerintah dalam usaha memperkokoh persatuan dan kesatuan bangsa serta meningkatkan amal untuk bersamasama membangun masyarakat sejahtera lahir dan batin (Kemenag RI, 1989:90). Prinsip kerukunan umat beragama ini dalam konteks keindonesiaan dipakai sebagai kerangka untuk menjaga stabilitas pembangunan nasional. Kerukunan hidup beragama menunjukkan pola hubungan antar berbagai kelompok umat beragama yang rukun, saling menghormati, saling menghargai dan damai, tidak bertengkar dan semua persoalan dapat diselesaikan sebaik-baiknya dan tidak mengganggu kerukunan hubungan antarumat beragama pada suatu daerah tertentu (Ali [ed.] 2009: 6). Umat beragama merupakan penganut suatu agama yang berkembang di masyarakat, seperti Islam, Nasrani, Hindu, dan Buddha. Sedang agama sendiri mempunyai tiga aspek, yaitu aspek kepercayaan, peribadatan, dan sosiologis. Ketiga aspek tersebut, aspek sosiologislah yang dapat memiliki hubungan antar sesama umat beragama.

\section{METODE PENELITIAN}

Penelitian ini menggunakan pendekatan kualitatif, cakupannya adalah masyarakat Bawean Gresik. Jenis penelitian kuantitaif ini mempunyai beberapa ciri, antara lain: setting yang aktual, peneliti adalah instrumen kunci, data bersifat deskriptif, menekankan kepada proses, analisis datanya bersifat induktif, dan meaning (pemaknaan) tiap event adalah merupakan perhatian yang esensial dalam penelitian kualitatif (Moleong, 2002: 3). Menurut Sugiyono (2010: 8), metode kualitatif disebut juga metode naturalistik, karena penelitiannya dilakukan pada kondisi yang alamiah (natural setting); disebut juga metode etnografi karena pada awalnya metode ini lebih banyak digunakan untuk penelitian bidang 
antropologi budaya; disebut kualitatif karena datanya dan analisisnya lebih bersifat kualitatif. Penggunaan metode kualitatif dimaksudkan untuk melaksanakan studi eksplorasi (exploration research) dan pengkajian atas keterlibatan masyarakat dalam menciptakan kerukunan berbasis kearifan lokal.

Metode yang digunakan dalam penelitian ini adalah kualitatif-deskriptif, artinya peneliti akan mencari deskripsi yang menyeluruh, mendalam, dan cermat tentang kearifan lokal (local genius) pada masyarakat Bawean Kab. Gresik. Sedang penyampaian secara deskriptif diharapkan mampu menggambarkan bagaimana kearifan lokal berperan dalam memelihara kerukunan umat secara terbuka alamiah (Anas Saidi, 2006). Penelitian ini dilakukan pada masyarakat Bawean, Kab. Gresik, terutama di Kec. Sangkapura dan Tambak dipilih dengan pertimbangan bahwa dua kecamatan tersebut merupakan daerah pesisir yang dengan karakteristik kearifan lokal yang masih eksis dan terdapat nilainilai kearifan lokal yang mampu membangun kerukunan hidup bersama. Pengumpulan data lapangan dilaksanakan antara bulan Februari sampai Mei 2014.

Teknik pengumpulan data dalam penelitian ini dilakukan melalui tiga cara, yaitu: wawancara mendalam, observasi terlibat dan teknik dokumentasi (Hb. Sutopo, 1988). Teknik analisis data yang digunakan adalah model analisis interaktif (interactive model of analysis) yang meliputi tiga tahapan, yaitu reduksi data, penyampaian data, dan penarikan kesimpulan (Imam Suprayogo dan Tobrani, 2003: 196). Untuk lebih menghargai perasaan informan peneliti menggunakan cara penyajian model emik dan etik. Sedang penarikan kesimpulan dilakukan dengan memperhatikan berbagai hal yang memiliki landasan data yang kuat dalam penelitian. Dalam penelitian ini, uji validitas data dilakukan dengan dua cara: pertama, triangulasi data (data triangulation), yaitu peneliti menggunakan beberapa sumber data untuk mengumpulkan data yang sama. Kedua, dengan review informan (informant review), yang dilakukan melalui diskusi, dialog, seminar, atau FGD.

\section{PEMBAHASAN}

Masyarakat Gresik secara etnis bersifat majemuk. Kebanyakan berasal dari suku Jawa dan Madura, lainnya merupakan suku Arab dan Cina (Mustakim, 2010: 19). Data statistik tahun 2012 menunjukkan bahwa penduduk Kab. Gresik sebesar 1.307.995 jiwa, yang terdiri dari 658.786 laki-laki dan 649.209 perempuan. Jumlah penduduk tersebut berada pada 356.685 keluarga. Dengan luas wilayah $1.191,25 \mathrm{~km}^{2}$, Kab. Gresik mempunyai kepadatan penduduk sebesar 1.098 jiwa $/ \mathrm{km}^{2}$. Pada Tahun 2012, jumlah penduduk laki-lakinya lebih banyak jika dibandingkan dengan penduduk perempuan. Hal ini dapat dilihat dari angka rasio jenis kelamin sebesar 101. Artinya, dari 100 jiwa penduduk perempuan terdapat 101 jiwa penduduk laki-laki (BPS Kab. Gresik, 2013: 35).

Penduduk Kab. Gresik berbeda dengan wilayah lainnya, yang biasanya, jumlah penduduk wanita lebih banyak. Kenyataan ini dipicu derasnya arus urbanisasi, karena Gresik sebagai daerah industri penyangga bagi Ibukota Provinsi Jawa Timur. Banyak pendatang yang mencari dan bekerja kemudian menetap di Kab. Gresik (Mustakim, 2010: 23). Pola urbanisasi dan indrustrialisasi ini juga akan berdampak pada aspek sosilogis masyarakat Gresik, sehingga terjadi pergeseran (shifting), yang semula penduduknya agamis dengan kota santri sebutannya menjadi kota yang multiagama. Selain itu, menurut Moh. Toha, budaya dari luar Gresik pun lambat laun masuk berkembang (penetrasi) sehingga perlu diantisipasi agar benar-benar tidak tercampur budaya yang merugikan generasi muda (Wawancara, 10/02/2014).

Data pemeluk agama mayoritas Islam sebanyak 1.140.275 jiwa, disusul Kristen 9.487 jiwa, Katholik 3.942 jiwa, Hindu 2.124 jiwa, Buddha 405 jiwa sedangkan yang beragama Konghuchu tidak terdaftar, tetapi sebenarnya ada. Ini dikarenakan Konghuchu secara formal merupakan agama baru, selama ini mereka menuliskan pada kolom data kependudukan beragama Budha. Selain itu, belum terdapat penduduk yang ber-KTP Konghuchu yang terdata di Kab. Gresik.

Kehidupan sosial masyarakat Gresik, termasuk Bawean, secara umum dipengaruhi oleh tingkat pengetahuan yang diperoleh lewat pendidikan agama. Sebelum pendidikan agama, disatukan dalam sistem pendidikan formal seperti sekarang ini, yang berlaku adalah pendidikan agama dengan metode tradisional yaitu pesantren (Mustakim, 2010: 19). Tidak hanya di pesantren, pendidikan agama juga diadakan di langgar/suara yang ada di setiap kampung dengan kyai masingmasing. Kesemarakkan syiar Islam dan banyaknya pesantren maupun pemuka agama di Gresik ini yang menjadikan orang menyebut kabupaten ini dengan sebutan "Kota Santri" (Wawancara dengan Umar Zaenoedin, 17/03/2014). 
Folklore sebagai "Kota Santri” nampak pada lembaga pendidikan agama yang ada di Gresik yang berjumlah 1.769. Lembaga tersebut terdiri atas Raudhatul Afthal/RA (187), Madrasah Ibtidaiyah Negrei/MIN (2), Madrasah Ibtidaiyah Swasta/ MIS (363), Madrasah Tsanawiyah Negeri/MTsN (1), Madrasah Tsanawiyah Swasta/MTsS (140), Madrasah Aliyah Negeri/MAN (2), Madrasah Aliyah Swasta/MAS (60), Madrasah Diniyah/ Madin (818), dan Pondok Pesantren (196). Ikon "Kota Santri" ditunjukkan selain dari bayaknya infrastruktur yang mendukung juga kesemarakan keberagamaan masyarakat (BPS Gresik, 2013: 162).

\section{Pulau Bawean Gresik}

Nama Bawean tidak diketahui secara pasti. Namun, ada beberapa cerita yang berkembang di masyarakat bahwa pada masa keemasan kerajaan Majapahit, Raja Hayam Wuruk dengan seorang panglima perang yang sangat sakti bertekad untuk mempersatukan Nusantara. Untuk itu, Hayam Wuruk mengutus pasukan penakluk baik darat maupun laut (armada laut) ke kerajaan-kerajaan kecil di wilayah seberang. Salah satu armada laut yang diutus ke arah utara sampai di tengah perjalanan mendapat musibah. Mereka di hantam badai laut, di terpa angin kencang, dan di selimuti kabut tebal terkatung-katung di tengah laut jawa. Banyak prajurit yang meninggal dunia karena kelaparan dan tidak kuat dengan keadaan alam yang menjebak mereka. Setelah berhari-hari bahkan bermingguminggu terombang-ambing di tengah laut, beberapa orang prajurit yang selamat tiba-tiba melihat samarsamar dari kejauhan nampak gugusan-gugusan gunung. Maka dengan sisa tenaga yang ada mereka segera menuju ke arah gugusan gunung itu, setelah sampai ternyata gugusan gunung yang mereka lihat dari jauh adalah sebuah pulau kecil.

Setelah bersandar, mereka dengan susah payah turun dari kapal dan pergi memasuki pulau asing yang ibarat kapal penyelamat datang memberi bantuan pada mereka. Sampai di daerah pemukiman penduduk, mereka disambut hangat oleh penduduk setempat. Karena rasa gembira yang begitu besar, dengan tanpa disadari keluarlah dari bibir Senopati Majapahit ungkapan singkat nan indah, "Ba-we$a n$ ". Ungakapan ini berasal dari bahasa Sansekerta, " $b a$ " artinya sinar, "we" berarti matahari, dan "an" artinya ada. Jadi kata "Bawean" secara terminologi berarti "ada sinar matahari". Sejak saat itu, mereka hidup di sana dan sejak saat itu pulalah pulau kecil penyelamat mereka di kenal dengan nama Pulau Bawean (http://kakmuqrialgelamy.blogspot. com/2011/04/kumpulan-cerita-pulau bawean.html, 10/04/2014).

Pulau Bawean secara administratif pemerintahan masuk wilayah Kab. Gresik, Propinsi Jawa Timur. Letaknya sekitar $150 \mathrm{~km}$ dari Ibukota Kab. Gresik ke arah utara wilayah Laut Jawa. Pulau ini dapat dicapai dari Gresik dengan kapal lambat selama kurang lebih 10 jam dan kapat cepat sekitar 4-5 jam. Pulau Bawean terbagi dua kecamatan, yaitu Kec. Sangkapura dengam 17 desa, berada dibagian selatan; dan Kec. Tambak dengan 13 desa, dibagian utara. Desa yang masuk Kec. Sangkapura meliputi: Kumalasa, Lebak, Bululanjang, Sungaiteluk, Kotakusuma, Sawahmulya, Sungairunjing, Daun, Sidigedungbatu, Kebun Teluk Dalam, Balikterus, Gunungteguh, PatarSelamat, Pudakit Timur, Pudakit Barat, Suwari, dan desa Dekatagung. Sedang desa di Kec. Tampak meliputi: Telukjatidawang, Gelam, Sukaoneng, Klompanggubuk, Sukalela, Pekalongan, Grejek, Paromaan, Kepuhlegundi, Kepuhteluk, Diponggo, Tanjungori, dan Tambak (Wawancara Amin dan Ali, 21/05/2014). Jumlah desa secara keseluruhan ada 30 desa dengan 143 dusun. Secara umum, dalam satu pulau ini mempunyai budaya, tradisi, dan adat istiadat yang hampir sama.

Menurut Amin, kepala KUA Kec. Sangkapura, jika dalam kondisi bagus, pulau ini dengan jalan lingkar sekitar $60 \mathrm{~km}$ ini bisa dikelilingi dalam tempo 3-3,5 jam dengan sepeda motor sambil bersantai (Wawancara Amin, 21/05/2014). Pulau ini memang cukup penuh dengan keindahan alam lingkungannya, sejarah, adat-istiadat, dan tradisi kebudayaan masyarakatnya, serta keramahtamahan penduduknya. Bawean merupakan gugusan pulau yang berada di wilayah Kab. Gresik sejak tahun 1974 dan dikelilingi oleh pulau-pulau kecil disekitarnya, seperti Pulau Gili, Selayar, Nuko, Nasa, Karangbila, Cina, dan lainnya. Ada tiga keunikan dan bahkan ikon bila orang luar melihat Bawean, yaitu: (i) anyaman tikar Bawean;( ii) ikan pindang; dan (iii) rusa Axis Kuhli (Rusa Bawean). Keunikan ini tidak lepas dari apa yang ada di alam Bawean, dan tidak terdapat di tempat lain. Anyaman tikar Bawean ada karena bahan baku yang cukup tersedia di desa tertentu, yaitu di Desa Gunung. Tikar Bawean dijual ke luar desa bahkan sering dijadikan souvenir oleh para penadatang yang berkunjung ke Bawean.

Ikan merupakan bahan pangan yang melimpah bagi masyarakat Bawean. Mengingat Bawean merupakan wilayah laut yang pada hampir tiap desa ada yang bermata pencaharian sebagai nelayan (Wawancara Ikbal, 22/05/2014). Ikan yang 
melimpah ini dibuat pindang untuk disajikan setiap waktu makan. Setiap waktu makan datang, menu ikan selalu menjadi menu utama. Lauk tempe tahu yang selalu terhidang di sebagian besar masyarakat Jawa, tetapi tidak ditemukan di Pulau Bawean (Observasi, 22-23/05/2014). Sedang rusa Bawean ada di penangkaran di tepi hutan masuk wilayah Desa Pudakit Timur, Kec. Sangkapura (Wawancara Amin, 22/05/2014). Untuk menuju lokasi penangkaran rusa dapat ditempuh dengan menyewa mobil atau sepeda motor.

Penduduknya Bawean merupakan pembauran beberapa suku yang berasal dari pulau Jawa, Madura, Kalimantan, Sulawesi, dan Sumatera termasuk budaya dan bahasanya (BPS Kab. Gresik, 2013: 41). Dilihat dari jenis kelaminnya, terdiri dari 58.713 laki-laki dan perempuan berjumlah 57.674 jiwa. Penduduk Bawean kebanyakan memiliki mata pencaharian sebagai nelayan, petani, selain juga menjadi TKI di Malaysia dan Singapura, sebagian besar di antara mereka telah mempunyai status penduduk tetap di negara tersebut, selain di kedua negara tersebut, penduduk Bawean juga menetap di Australia dan Vietnam. Etnis mayoritas penduduk Bawean adalah Suku Bawean, dan suku-suku lain misalnya Suku Jawa, Madura, Bugis, Mandar, Mandailing, Banjar, dan Palembang.

Bahasa Bawean ditengarai sebagai kreolisasi bahasa Madura, karena kata dasarnya yang berasal dari bahasa ini, namun bercampur aduk dengan bahasa Jawa, Melayu, dan Inggris, karena banyaknya orang Bawean yang bekerja atau bermigrasi ke Malaysia dan Singapura. Bahasa Bawean memiliki ragam dialek, biasanya setiap kawasan atau kampung mempunyai dialek bahasa sendiri seperti Bahasa Bawean Dialek Daun, Dialek Kumalasa, Dialek Pudakit, dan Dialek Diponggo. Bahasa ini dituturkan di Pulau Bawean, Gresik, Malaysia, dan Singapura. Untuk Malaysia dan Singapura, Bawean dikenal sebagai Boyanese. Intonasi orang Bawean mudah dikenali di kalangan penutur bahasa Madura. Perbedaan kedua bahasa dapat diibaratkan dengan perbedaan antara bahasa Indonesia dan bahasa Malaysia, yang serupa tapi tak sama meskipun masing-masing dapat memahami maksudnya. Menurut Iqbal, bahasa asli Bawean seperti Bahasa Jawa, tetapi bukan Bahasa Jawa sebagai yang dipakai masyarakat Jawasecara luas, tetapi telah mengalami perubahan fonem, dialek, dan ujaran, seperti yang ada di Desa Diponggo.

\section{Bentuk Kearifan Lokal Masyarakat Bawean}

Kearifan lokal yang dikemukakan di sini dibatasi pada tradisi, seni, dan budaya di Bawean, yang merupakan bagian kecil dari Kab. Gresik. Bawean bagi masyarakatnya sebagai pulau tempat lahir dan tempat mati. Sebab, orang Bawean kalau besar merantau dan kalau sudah tua kembali ke Bawean. Ada prasasti yang terbaca apabila berkunjung ke pulau Bawean, yaitu: "Bawean hanya untuk lahir dan mati" (Wawancara Iqbal, 15/03/2014). Adapun kearifan lokal masyarakat Bawean dapat ditemukan dalam beberapa tradisi dan budaya yang berkembang di daerah tersebut, seperti tradisi pengantin amaen dan pencak Bawean. Pertama, tradisi pengantin amaen. Tradisi pengantin bermain merupakan salah satu bagian dari prosesi pernikahan. Prosesi perkawinan di Bawean berbeda di tempat lain, terutama dalam hal proses melamar. Pihak perempuan melalui orang tua melamar pihak laki-laki, maka laki-laki mempunyai daya pilih (bergaining position) yang tinggi. Jika diterima lamarannya, barulah proses perkawinan selanjutnya dilaksanakan. Kedatangan laki-laki ke perempuan menjelang akad nikah, membawa berbagai keperluan rumah tangga diantar sanak kerabatnya. Setelah akad nikah dan resepsi selasai maka ada proses berikutnya.

Budaya Bawean dalam prosesi penikahan adalah pengantin amaen. Prosesi amaen dipahami sebagai kegiatan keluarga besar mempelai putri mendatangi keluarga mempelai putra. Kedatangannya dengan membawa oleh-oleh yang diberikan kepada pihak yang didatangi, tujuannya adalah mengenalkan isterinya kepada keluarga sang suami. Pada proses ini tidak hanya keluarga mempelai puteri saja yang ikut, tapi selutuh keluarga besar pengantin wanita ikut mengiringi sehingga terkesan besar-besaran. Kekompakan dan kebersamaan keluarga sangat terlihat di sini. Sanak famili dari keluarga pengantin puteri mendukung proses ini sehingga kadang hampir satu desa berpartisipasi. Pada gilirannya nanti, keluarga bergantian mendukung keluarga besar lainnya. Pada saat proses biasanya sambil menyebar uang baik ribuan, puluhan ribu, bahkan seratus ribu terkadang disebar. Pokoknya siapa yang merasa keluarga besarnya ikut prosesi. Saat menyebar uang maka warga berebut uang terutama anak-anak sehingga semarak dalam acara tersebut (Wawancara Iqbal, 15/03/2014).

Kedua, pencak Bawean. Pencak Bawean biasanya dimainkan saat ada acara pernikahan. Semula setiap ada acara pernikahan, jawara 
kampung didatangkan untuk mencoba kembali kemampuan ilmu bela diri dengan membawa tiga orang pengikut. Sekarang mereka tidak membawa tiga orang laigi, tetapi membawa banyak pengikut sehingga tuan rumah kewalahan dalam memperkirakan konsumsinya (Ya'kup, 28/09/2010). Biasanya diawali dengan adu pedang, dilanjutkan dengan duel tangan kosong. Keduanya sampai begulingan di atas panggung. Inilah pencak silat Bawean. Atraksi ini biasa ditampilkan pada momentum tertentu. Dulu, pencak silat memang sangat terkenal di Bawean. Hal ini meruipakan bekal wajib bagi seorang yang akan ditasbihkan menjadi lelaki. Pencak silat juga menjadi sarat utama, sebelum kaum lelaki Bawean merantau. Menurut Iqbal, seorang pendekar (dibaca: pan-dhikar) keberadaannya dan juga keluarganya, sangat dihormati dan ditokohkan oleh warga setempat, karena selain mereka dapat memberikan rasa aman, juga menjadi tumpuan penduduk untuk berobat.

Banyak pendekar menguasai ilmu tabib, bahkan mereka dapat menyembuhkan orang patah tlang dengan hanya menyiramkan air. Namun, mereka tidak mau disebut dukun, karena mereka tidak memelihara jin, sebagaimana umumnya dimiliki dukun-dukun di Bawean. Karena ilmunya pula, seorang pendekar juga disegani kawan maupun lawan juga ditakuti. Dulu, jika penduduk akan membangunkan pendekar yang tengah tidur, mereka tak boleh menyentuh badannya, sebab bisa menjadi korban jurus refleks sang pendekar. Tetapi ada caranya untuk membangunkan pendekar, yaitu harus berdiri dari jarak sekitar $1 \mathrm{~m}$, lalu sentuhlah ujung jemari kakinya, sembari memanggil namanya dengan halus. Dengan demikian, si pendekar akan bangun tanpa melukai (Wawancara Ikbal, 15/03/2014).

Setiap pendekar memiliki karakteristik ilmu silat berbeda, jurus-jurus ilmu ini mereka adopsi atau menggabungkan ilmu silat dari China, Malaysia, dan Jawa. Keahlian tertentu dimiliki oleh seorang pendekar seperti pendekar ahli kuntau, ada yang ahli memakai senjata tajam, semisal tombak dan trisula (orang Bawean biasa menyebut tik-pie). Adapun daerah yang banyak memiliki pendekar terkenal adalah Desa Daun dan Gunung Teguh Kec. Sangkapura. Biasanya, mereka memiliki perguruan silat sendiri, di aman semakin besar nama si pendekar, semakin banyak pula muridnya hingga merambah daerah lain. Anak muda Bawean akan bangga jika menjadi murid seorang pendekar besar atau biasa dipanggil pan-dhi-kar raje. Strata pergaulan ikut naik dan disegani oleh kawan maupun lawan. Para pendekar dari kampung-kampung yang datang ditampilkan secara bergantian sebagaimana layaknya pertandingan. Makin sering menang semakin dikenal masyarakat. Bawean yang alamnya tidak begitu subur menjadikan penghuninya harus berpikir dan berusaha keras untuk mempertahankan hidupnya. Biasanya peserta dari anak muda terutama yang menginjak dewasa dan menjelang pergi merantau. Bela diri ini pada hakekatnya untuk membekali diri saat pergi jauh untuk merantau di negeri orang.

\section{Seni Tradisi Bawean}

Bawean sejak dulu dikenal sebagai pulau untuk persinggahan beberapa etnis dari seluruh wilayah Nusantara, sehingga tidak mengherankan jika pulau ini memiliki kesenian dan tradisi yang beragam. Ada beberapa seni tradisi yang masih bertahan dan dilestarikan masyarakat Bawean hingga kini, diantaranya Bangsawan, Jibula, Saman, Mandiling, Korcak, dan Kercengan. (1) Bangsawan (dibaca: bangsawen). Seni tradisi ini diadopsi dari Melayu, sejenis ketoprak Jawa atau drama, yang berkisah tentang kaum bangsawan (raja-raja) terdahulu di negeri Melayu. Bangsawen biasa dipentaskan pada acara-acara khusus, dan kesenian ini terakhir dipentaskan pada masa pra-kemerdekaan. Pada tahun 1930-an, Mahmud Said, lurah di Kotakusuma kerap mementaskan Bangsawan dengan jumlah pemain sangat banyak, mencapai 30-an. Uniknya, semua pemainnya bukan penduduk asli Bawaean, namun didatangkan dari Jawa. (2) Jibula, kesenian yang diadopsi dari Aceh. Kesenian ini merupakan tradisi dongeng, di mana seorang lelaki tunanetra akan melantunkan kisah-kisah rakyat. Mirip pementasan yang dilakukan pendongeng asal Aceh, PM. Toh. Jibula marak dipentaskan di Bawean pada tahun 1950-an ke bawah.

Selanjutnya seni (3) saman (dibaca: samman). Seni tari yang diadopsi dari Aceh, dan di. Bawean, seni tari ini sudah jarang dipentaskan; (4) Mandiling, merupakan grup seni pantun, sekarang masih tetap eksis dan sering dipentaskan. Biasanya, mereka berkelompok, di antara mereka ada beberapa yang menabuh gendang lonjong dan gong. Selanjutnya, orang lelaki berkebaya mirip perempuan, akan tampil menari sambil berpantun jenaka. Kadang pula pementasan ini melibatkan penonton, sehingga membuat mandiling meriah; (5) Korcak, sebuah seni dimainkan secara berkelompok. Semua pemainnya adalah laki-laki. Mirip saman, mereka berbaris rapi lalu menyanyikan lagu padang pasir (nasyid, gambus), sambil menabuh rebana. 
Penari memegang rebana sambil mengayunkan langkah ke kanan ke kiri. Pengiring lain berjajar di sebelah pinggir. Tampak serasi dan kompak serta menyenangkan. Pada saat ada even atau kedatangan tamu atau kunjungan pejabat pejabat, tari ini dimainkan di dermaga Bawean saat kapal merapat dan pengunjung bergegas turun ke daratan (Observasi, 22/05/2014).

Ada kesenian (6) Samrah. Seni ini masih eksis dan dipentaskan, dan semua pemainya adalah perempuan, biasanya mereka menyanyikan lagu qasidah sambil menabuh rebana. Hampir di perkumpulan bernafaskan Islam, baik remaja maupun dewasa memiliki grup ini. Di Bawean, beberapa organisasi memiliki grup Samrah. Salah satu yang eksis yaitu grup samrah binaan Muslimat NU Kec. Tambak. Anggota grup Samrah rata-rata masih remaja. Pementasan Samrah pada saat ada kegiatan keagamaan yang melibatkan berbagai unsur masyarakat di daerah tambak; dan (7) Kercengan, merupakan perpaduan antara saman dan samrah. Dipentaskan sekelompok wanita dengan duduk berbaris. Mereka berseragam dan memakai sarung tangan warna putih. Kemudian mereka menggerakkan tangan ke sana-kemari, diiringi alunan irama padang pasir/gambus. Berbeda dengan samrah yang hanya memakai rebana, Kercengan, menggunakan alat musik apapun diperkenankan. Hingga saat ini, selain kerap dipentaskan, Kercengan juga kerap dilombakan (Wawancara Ikbal, Amin, Ali, 22/05/2014).

\section{Budaya Merantau Orang Bawean}

Migrasi merupakan tradisi dan kebudayaan yang telah mengakar kuat bagi masyarakat Bawean. Menurut Rebecca (dalam Rahman, 2010: 24), tradisi merantau bagi orang Bawean disebabkan adanya sejarah yang panjang bekerja di luar negeri. Pada umumnya orang laki-laki diharapkan pergi ke negara lain sedikitnya satu kali. Dari argumentasi berdimensi kultural tentang migrasi, Bawean yang diberikan memang tampak dengan jelas bahwa bermigrasi, terutama ke luar negeri bagi masyarakat Bawean, memang sudah merupakan sebuah tradisi kebudayaan (habits of culture). Ia menjadi sebuah tradisi kebudayaan karena dalam khasanah budaya dan kebudayaan mereka bermigrasi/merantau menjadi sebuah prasyarat yang semestinya didahulukan sebelum membentuk rumah tangga atau ikatan perkawinan. Kebudayaan merantau ini diungkapan dalam sebuah pantun,

Jangan membuka sewek; Kalau belum mengukir langit;
Dan jangan mengukir langit; Kalau belum menguasai ilmu lahir dan batin.

Arinya: Jangan kawin; Sebelum merantau;

Jangan merantau sebelum menguasai ilmu lahir; (llmu lahir yakni mahir dalam permainan silat);

Jangan merantau sebelum menguasai ilmu batin; (llmu batin yaitu tamat (khatam) AlQuran, paham kitab Safinah, dan Mampu melagukan Barzanj dengan bagus).

Pada ungkapan di atas, senada dengan Iqbal (Informan, 15/03/2014) bahwa merantau diibaratkan sebagai "mengukir langit", sesuatu yang sangat fantastis dan merupakan suatu tantangan untuk dicapai bagi setiap orang di Bawean. Tentunya sedapat mungkin dilakukan salah satu anggota dari setiap keluarga. Seorang informan penelitian menyatakan, setiap rumah tangga di Bawean, pasti ada salah satu anggotanya ada yang "merantau", ke daerah mana saja. Merantau, bagi para pemuda dan pemudi adalah suatu syarat sebelum memasuki perkawinan, membentuk mahligai rumah tangga. Ada pribahasa lain yang menyatakan bahwa "gantungkanlah cita-citamu setinggi langit", ternyata bagi orang Bawean sudah terlampaui karena, bagi mereka, bukan lagi hanya cita-cita yang perlu bersentuhan dengan langit, tetapi lebih jauh dari itu mereka ingin melukis langit. Langit dengan latar belakang warnanya yang biru sebenarnya sudah sangat indah, tetapi bagi orang Bawean, masih akan diperindah lagi melalui tindakan "melukis", yaitu dengan jalan merantau ke daerah/negeri lain (Rahman, dkk., 2010: 25).

Bertolak dari adanya ungkapan tersebut dan maknanya yang menekankan beberapa hal yang harus terpenuhi terlebih dulu sebelum merantau menunjukkan bahwa untukmerantau persiapan yang lengkap, matang, harus betul-betul dipersiapkan. Merantau bukan hanya mempersyaratkan adanya bekal biaya yang cukup atau segala sesuatu yang berwujud material, tetapi juga persiapan yang bersifat immaterial, yaitu bekal ilmu lahir dan batin. Meskipun tradisi merantau itu pada mulanya dirintis oleh kaum laki-laki, tetapi dalam perkembangannya sejak awal juga bersentuhan dengan semua anggota keluarga baik laki-laki maupun perempuan.

Merantau adalah tumpuan utama dan strategi bertahan hidup yang paling penting bagi masyarakat Bawean. Migrasi, terutama ke luar negeri (Singapura, Malaysia, Amerika Serikat, Pulau Chrismast Australia, dan lain-lain) tidak hanya menyangkut 
ketahanan untuk kehidupan ekonomi semata, tetapi sudah bertalian pula dengan ketahanan sosial, budaya, politik masyarakat Bawean. Sukses migrasi bahkan juga akan menjadi penentu bagi suksesnya pembangunan Pulau Bawean dan masyarakatnya pada masa-masa yang akan datang (Wawancara Iqbal, 15/03/2014).

\section{Perayaan Maulud warga Bawean}

Setiap tahun, perayaan Maulud Nabi Muhamma saw. selalu diadakan di masing -masing langgar/masjid. Setiap warga membuat angkatan (Jawa: buceng, tumpeng) sesuai dengan kadar kemampuannya. Angkatan yang dibuat dibawa ke masjid/surau dengan maksud akan diberikan kepada orang yang dikehendaki, biasanya sesepuh, guru ngaji, atau kyai. Angkatan berisi nasi, lauk pauk dan buah. Ada juga diselipkan barang berharga seperti uang atau emas di antara isi angkatan tersebut (Wawancara Iqbal, 15/03/2014). Pada tahun 2013, perayaan Maulud Nabi diadakan juga di Kota Gresik. Panitia berasal dari Ikatan Masyarakat Bawean. Sebelumnya, panitia mengumumkan kepada warga Bawean di Gresik untuk mendaftarkan diri. Panitia memberi batasan "angkatan" dan isinya. Pada hari pelaksanaan semua tokoh hadir, termasuk yang berasal dari pulau Bawean. Bupati dan Wakil Bupati juga hadir. Setelah selesai "angkatan" yang disiapkan warga Bawean ini di lelang kepada yang hadir. Salah satu angkatan itu berhasil dilelang dengan nilai $\mathrm{Rp}$ 150 juta kepada Bupati Gresik (Wawancara Iqbal, $15 / 05 / 2014)$.

\section{Nilai Kerukunan pada Kearifan Lokal Masyarakat Bawean}

Budaya, adat istiadat, dan tradisi di Gresik umumnya, dan Bawean pada khususnya, masih eksis di tengah berbagai perubahan yang ada sesuai pola pikir masyarakat pelakunya. Budaya ini tidak punah karena di dalamnya mengandung nilai atau khikmah yang dapat dipetik menjadi pelajaran dan bermanfaat dalam kehidupan bermasyarakat bagi masyarakat itu sendiri. Prinsip Kerukunan bertujuan untuk mempertahankan masyarakat dalam keadaan yang harmonis (Suseno, 1985:39 dalam Suryadi, M, 2012: 70). Beberapa nilai kerukunan pada kearifan lokal masyarakat Bawen dapat dilihat dari tradisis yang dikembangkannya.

\section{Nilai Kerja Sama dalam Seni Tradisi}

Pada tradisi penganten amaen melibatkan keluarga besar yang tidak sedikit. Mereka yang merasa keluarga dari mempelai wanita akan bergerak dan membantu dengan sendirinya manakala saudarany sedang mempunyai hajat. Hampir seluruh masyarakat menyaksikan kebersamaan dan saling membantu yang ditunjukkan keluarga besar mempelai wanita. Hal ini menyebabkan arakarakan atau iring-iringan yang panjang dan ramai ketika rombongan menuju orang tua mempelai pria. Rombongan ada yang berjalan kaki, sepeda motor, dan juga mobil. Sikap membantu memenuhi kebutuhan dan tolong menolong ini merupakan poin yang dapat dijaga kelestariannya.

Sedang pada seni Kercengan yang merupakan perpaduan antara saman dan samrah, juga mengandung nilai kerjasama. Terlihat dari sekelompok wanita akan duduk berbaris, berseragam dan memakai sarung tangan warna putih. Mereka akan menggerakkan tangan ke sana-kemari dengan iringan alunan irama padang pasir. Dalam gerak membutuhkan perhatian dan konsentrasi yang tinggi. Sangat susah dilaksanakan oleh orang yang tidak memiliki sikap kerja sama yang baik. Sehingga nilai kerjasama dan bersatu menjacap tujuan sangat diperlukan. Seni ini mengilhami masyarakat untuk dapat menyatukan gerak langkah dan bersatu dalam mencapai masyarakat yang diinginkan bersama. Dalam folklore Jawa disebutkan bahwa: "rukun agawe santoso, crah agawe bubrah", "guyup rukun saeko kapi", dan ungkapan lain yang mengandung makna ke arah kerjasama. Dengan demikian, tradisi ini merupakan tradisi yang sesuai dengan prinsip rukun yang dikemukakan Suseno bahwa rukun berarti menjaga kondisi agar tetap berada dalam keadaan selaras, tenang dan tentram, tanpa perselisihan, tanpa pertentangan, bersatu dalam maksud untuk saling membantu.

\section{Toleransi dalam Pencak Bawean}

Pencak Bawean ini merupakan bekal wajib bagi seorang yang akan ditasbihkan menjadi lelaki dan menjadi sarat utama, sebelum kaum lelaki Bawean merantau. Orang yang mahir memainkan pencak silat ini disebut pendekar. Keberadaan seorang pendekar juga keluarganya, sangat dihormati dan ditokohkan oleh warga setempat, karena selain mereka dapat memberikan rasa aman, juga menjadi tumpuan penduduk untuk berobat.

Ketika ditanya apakah pernah terjadi perselisihan antar desa karena pendekarnya kalah dalam bertanding, Iqbal (48), menyebut bahwa perselisihan antar kampung belum pernah terjadi. Mereka sudah menyadari bahwa pencak itu sebagai bekal sebelum meninggalkan kampung halaman. Penghormatan kepada yang menang tetap ada, 
tetapi yang menang tidak merendahkan yang kalah. Permainan ini tidak sampai melukai satu sama lain. Ada wasit dari kalangan sesepuh yang akan menghentikan apabila lawan sudah dianggap kalah. Ini sudah ditaati oleh semua pendekar yang ada. Pendekar tetap akan menghormati dan percaya dengan keputusan pemimpin pertandingan. Permainan diikuti seluruh utusan jawara dan tidak dibeda-bedakan asal usul, apalagi etnisnya.

Tradisi pencak ini sesuai dengan Suseno dalam Suryadi (2012: 70) mengedapankan prinsip hormat, yang merupakan sebuah pengakuan atas kedudukan masing-masing pada tatanan sosial yang terbentuk dalam kehidupan dan memiliki cita rasa, serta dijaga oleh masing-masing individu untuk menjaga dan menyeimbangkan keselasan. Namun, pelestarian tradisi ini diharapkan tidak hanya untuk kepentingan budaya dan pariwisata saja tetapi dapat memberi pelajaran yang bermakna bagi masyarakat untuk menjaga kerukunan dalam lingkup yang luas.

\section{Memuliakan Tamu}

Selain itu, budaya memuliakan tamu sangat dijunjung tinggi oleh masyarakat Bawean. Mereka sangat percaya bahwa tamu merupakan orang yang patut dihormati. Tidak memandang siapapun yang datang. Dicontohkan Ikbal (48 Th), kalau ada tamu apalagi dari luar pulau, mereka akan menghidangkan yang terbaik yang dia miliki. Mungkin minuman susu bagi tamu sudah biasanya, tapi itu terbaik karena sangat susah untuk mendatangkannya, yaitu dari luar pulau. Ini tidak lain didorong semangat mengamalkan ajaran agama yang mereka anut selama ini. Ketaatan pada ajaran agama yang telah mendarah daging dalam kehidupan ini berlaku tidak hanya untuk seseorang yang sudah kenal saja, tetapi penghormatan ini bagi semua tamu tidak memandang ras atau agamanya.

Masyarakat Bawean mempunyai bangunan khas rumah panggung yang terletak di depan kanan atau kiri rumah. Bentuknya seperti gubuk yang disebut Dhurung Bawean. Bangunan ini awalnya beratapkan daun ilalang atau ijuk, namun saat ini sudah berubah menjadi seng atau genteng. Di bawah atap ada ruang yang biasanya untuk meletakkan hasil-hasil pertanian seperti padi, jagung, dan lainlain. Kurang lebih $1 \mathrm{~m}$ dari tanah dibuat alas tempat duduk. Disitulah awalnya, apabila ada tamu datang maka diterima di Dhurung Bawean yang telah ada hampir di setiap rumah. Di dekat Dhurung, ada juga tungku untuk memasak sehingga sajian yang dihidangkan langsung bersala dari api yang masih hangat rasanya. Kegunaan lain, dari api tersebut untuk lebih cepat mengeringkan bahan makanan yang disimpan di bawah atap tersebut sehingga cepat kering. Bahan pangan ini akan dikeluarkan pada saat dibutuh. Misalnya saat ada tamu datang atau saat terjadi musim kemarau yang sangat panas.

Dalam hal bahasa, masyarakat Sangkapura dan Tambak tidak berbeda dengan masyarakat Gresik secara umum. Bahasa mereka berbeda, seperti Jawa, tetapi bukan Jawa bukan pula Madura, meskipun seperti Madura. Bahasa dalam hal ini terbuka, tidak mengenal tingkatan dalam penuturannya. Sehingga semua orang dianggap sama. Tidak seperti bahasa Jawa yang akan berbeda cara berkomunikasi (Jawa: ondo usuk) dengan teman sebaya (ngoko), orang tua (kromo Inggil), dan kalangan bangsawan. Egaliter dalam bahasa ini menjadikan sifat khas dari masyarakat Gresik. Meskipun perilaku hormat terhadap yang lebih tua tetap tertanam sesuai tuntunan agama yang dianutnya.

\section{Solidaritas dalam Budaya Merantau}

Ketika ditanya bagaimana Pulau Bawean dikatakan bahwa tempat lahir dan tempatnya mati, bahwa kehidupan orang Bawean dari hasil merantau. Sehingga saat lahir di Bawean besar merantau dan ketika tua kembali lagi ke kampung halaman. Untuk bekal merantau tidak hanya berangkat saja, tetapi harus mempunyai persiapan yang matang.

Ungkapan yang telah dikemukakan di atas berarti bahwa jangan dulu berkeluarga kalau belum merantau dan jangan dulu merantau kalau belum menguasai ilmu lahir, yaitu mahir dalam permainan pencak Bawean (bela diri) serta jangan dulu merantau kalau belum menguasai ilmu batin, yaitu ilmu agama berupa khatam Al-Qur'an, paham kitab kuning Safinah, dan mampu melagukan kitab Al-Barzanji dengan bagus. Falsafah ini menjadi semangat bagi masyarakat Bawean untuk belajar pencak Bawean dengan tekun sejak usia dini. Ilmu agama juga dipelajari sejak dini. Ini dapat dilihat dari dominannya lembaga pendidikan agama, baik tingkat dasar, menengah, ataupun perguruan tinggi agama ada di Bawean. Ini sesuai dengan tuntunan ajaran Islam bahwa orang Islam wajib menuntut ilmu, baik ilmu lahir mapun bathin. Kewajiban ini tidak mengenal usia tetapi dari kandungan sampai liang lahat. Selain itu, tuntunan yang berisi bahwa kalau ingin berhasil hidup di dunia maka dengan ilmu, kalau ingin berhasil hidup di akhirat maka dengan ilmu dan kalau ingin kedua-duanya, maka dengan ilmu (hadis).

Falsafah yang bernuansa ajaran agama tersebut menjadikan masyarakat di Kec. Sangkapura 
dan Tambak Gresik berkemauan keras untuk membuktikan bahwa mereka berhasil ketika merantau dengan segala persiapan lahir dan batin. Keberhasilan ini didukung oleh solidaritas warga yang merantau terlebih dulu.

Ketika ada warga Bawean merantau, biasanya akan ditampung dalam suatu keluarga yang sudah berada di perantauan. Keluarga dalam arti mereka yang sudah berumah tangga dan mempunyai tempat tinggal ataupun perkumpulan dari orangorang Bawean di pearantauan. Bahkan di Singapura, orang Bawean mempunyai pondok tempat berkumpul. Pondok ini digunakan untuk tempat tinggal warga Bawean yang baru datang. Mereka akan menanggung segala keperluan hidup sampai pendatang tadi mulai mandiri. Begitu seterusnya, sehingga tidak terjadi orang Bawean tidak eksis di daerah perantauan. Selain itu, semangat dan kerja keras yang menjadi mereka berhasil di luar kampung halaman (Wawancara Ikbal, 22/05/2014). Sejalan dengan tradisi itu, Suryadi (2012: 70) menyatakan bahwa aspek etos kerja yang berlandaskan ajaran agama (Islam) sebagai pendorong dan motivator dalam melaksanakan bermacam-macam kegiatan untuk mencapai target yang dicita-citakan dan, bahkan sebuah bentuk panggilan bagi dan tantangan dalam pemanfaatan lingkungan laut sekitar pulau untuk memenuhi kebutuhan hidup keluarga dan warga masyarakat pulau lainnya.

Selain itu, pada saat seseorang berangkat merantau ada budaya ngater anteraken yang masih berlangsung. Masyarakat akan mengantar calon perantau sampai dermaga pelabuhan. Pengantar sangat banyak sehingga dermaga dipenuhi ribuan pengantar. Mereka berangkat dengan bersepeda motor, mobil pick-up, dan lain secara beriringan. Rasa solidaritas dan kebersamaan ini menjadikan kontak sosial di antara masyarakat sehingga dapat mempererat hubungan di antara warga yang pada akhirnya akan menguatkan ikatan persaudaraan secara luas.

\section{PENUTUP}

Gresik merupakan Kota Santri dengan rasa kota budaya, yang mempunyai berbagai macam tradisi dan adat. Seperti masyarkat lain, Bawean memiliki kearifan lokal yang masih bisa untuk dipertahankan dan patut dilestarikan karena msih fungsional dan sesuai dengan tuntutan perkembangan zaman. Beberapa seni, adat, dan keudayaan Bawean dipandang sebagai kearifan lokal yang masih dijadikan acuan (frame) dalam mengarungi kehidupan sehari-hari. Maka, revitalisasi kearifan lokal dalam berbagai bentuknya menjadi agenda yang mendesak untuk menjaga keseimbangan kehidupan masyarakat. Dari uraian di atas, dapat dipahami bahwa kearifan lokal yang ada di Bawean Kab. Gresik, yaitu di Kec. Sangkapura dan Tambak, antara lain: pengantin amaen, pencak Bawean, perayaan Maulud Nabi Muhammad saw., budaya merantau, dan berbagai jenis kesenian Islam. Kearifan lokal dalam berbagai bentuknya tersebut mempunyai nilai kerukunan antara lain: sikap saling menghormati, bernilai kerja sama, memfasilitasi dalam pemenuhan kebutuhan, sikap saling percaya, sikap tolong menolong, sikap toleransi, dan segala persoalan dapat diselesaikan dengan baik.

\section{UCAPAN TERIMA KASIH}

Tulisan ini hadir atas dukungan dari berbagai pihak. Saya mengucapkan terima kasih kepada keluarga besar Balai Penelitian dan Pengembangan Agama Semarang, Kepala Kantor Kementerian Agama Kabupaten Gesik, informan baik saat maupun pasca lapangan seperti Ikbal (kemenag), Amin (KUA Sangkapura), Ali (KUA Tambak), Hanafi, Ghofar, Idea Riseta P, Mibtadin dan lainlain yang tidak dapat disebutkan satu per satu. Tidak lupa terima kasih kepada motivator setia Prihatini Sulistyaningsih (istri), Nazalia Rosadanti Hanan 'Adila dan Hanifa Rosadanti Adnani (anak). Juga kepada tim al-qalam yang mengapresiasi tulisan ini. Semoga Allah Swt membalas semua kebaikannya. Amin

\section{DAFTAR PUSTAKA}

Abdullah, Irwan. dkk. (ed.). 2008. Agama dan Kearifan Lokal dalam Tantangan Global. Yogyakarta: Pustaka Pelajar.

Ali, Mursyid (ed.). 2009. Pemetaan Kerukunan Kehidupan Beragama di Berbagai Ddaerah di Indonesia. Jakarta: Puslitbang Kehidupan Keagamaan Badan Litbang dan Diklat Departemen Agama.

BPS, 2013. Gresik dalam Angka Tahun 2013. Gresik: BPS Kabupaten Gresik.

Departemen Agama RI. 1989. Pedoman Dasar Kerukunan Umat Beragama. Jakarta: Sekretariat Jenderal Departemen Agama Republik Indonesia.

Hendrajaya, Lilik. dkk. 2010. Ragam Konflik di Indonesia: Corak Dasar dan Resolusinya. Badan Penelitian dan Pengembangan Kementerian Pertahanan kerjasama dengan Kementerian Riset dan Teknologi. diperoleh dari: http://km.ristek.go.id/assets/ 
files/RAGAM\%20KONFLIK\%20DI\%20 INDONESIA.pdf, diakses 14 Januari 2014.

Jati, Wasisto, Raharjo,. 2013. "Kearifan Lokal sebagai Resolusi Konflik Keagamaan". Jurnal Walisongo Vol. 21 Nomor 2, November 2013

Moleong, Lexy P. J. 2002. Metodologi Penelitian Kualitatif, Bandung: Remaja Rosdakarya.

Mustakim. 2010. Gresik Dalam lintasan Lima Zaman Kajian Sejarah Ekonomi, Politik, Sosial, dan Budaya. Yogyakarta: Pustaka Eureka.

Neuman, W Lawrence. 2013. Metodologi Penelitian Sosial: Pendekatan Kualitatif dan Kuantitatif, edisi 7. Diterjemahkan oleh Edina T Sofia. Jakarta: Indeks.

Rachman, Patji Abdul. 2010. "Strategi Bertahan Hidup Pada Masyarakat Pulau Kecil dan Terpencil Pulau Perbatasan dan Pulau Sengketa: Studi Etnografi Budaya”. Laporan Akhir Program Insentif Peningkatan Kemampuan Peneliti dan Perekayasa LIPI Kementerian Riset dan Teknologi Di Lingkungan LIPI. Jakarta: Pusat Penelitian Kemasyarakatan dan Kebudayaan Lembaga Ilmu Pengetahuan Indonesia (PMB-LIPI).

Saidi, Anas. 2006. Bahan Workshop Pengembangan Penelitian Non-Positivistik Bagi Dosen-Dosen PTAI Se-Indonesia, Wisma Haji Armina Donohudan Boyolali, P3M STAIN SurakartaDitjen Binbaga Islam Depag RI
Sugiyono. 2012. Metode Penelitian Kuantitatif, Kualitatif, dan R\&D (cet. 12). Bandung: Alfabeta.

Sutopo, Harbertus. 1988. Pengantar Penelitian Kualitatif. Dasar-dasar Teoretis dan Praktis, Surakarta: Pusat Penelitian UNS.

Suprayogo, Imam dan Tobroni. 2003. Metodologi Penelitian Sosial Agama, Bandung: Remaja Rosdakarya.

Suryadi, M. "Tipe Kesantunan Tuturan Jawa pada Masyarakat Jawa Pesisir" Kajian Linguistik dan Sastra. Vol. 24, No. 1, Juni 2012.

Thohir, Mudjahirin. 2005. Kekerasan Sosial di Pesisir Utara Jawa. Semarang: Lengkongcilik Press bekerjasama dengan Puslit Sosial Budaya Lemlit UNDIP.

Wisnumurti, AA G Oka. Mengelola Nilai Kearifan Lokal dalam Mewujudkan Kerukunan Umat Beragama. Satu Tinjauan EmpirisSosiologisdikases dari alamat web: http:// www.yayasankorpribali.org/artikel-danberita/59-mengelola-nilai-kearifan-lokaldalam-mewujudkan-kerukunan-umatberagama.html, diakses 13 Januari 2014 2013. Potensi dan Produk Unggulan. Berani Bersaing dalam Pasar Global.Gresik: Bag. Adm. Perekonomian Sekda Kab. Gresik. 